\title{
Cross species amplification and characterization of microsatellite markers in Leporinus friderici (Characiformes, Anostomidae)
}

\section{Caio Felipe da Silva ${ }^{1}$ Diego Galetti Martins ${ }^{1}$ (i) Fernanda Dotti do Prado DiD $^{(}$ Ricardo Utsunomia ${ }^{3}$ (i) Fausto Foresti ${ }^{2}$ (I) Fábio Porto-Foresti ${ }^{1}$ (i)}

${ }^{1}$ Faculdade de Ciências, Universidade Estadual Paulista (UNESP), Bauru, SP, Brasil.

${ }^{2}$ Instituto de Biociências, Universidade Estadual Paulista (UNESP), 01049-010, Botucatu, SP, Brasil. E-mail: fp.foresti@unesp.br. ${ }^{*}$ Corresponding author.

${ }^{3}$ Departamento de Genética, Instituto de Ciências Biológicas e Saúde (ICBS), Universidade Federal Rural do Rio de Janeiro (UFRRJ), Seropédica, RJ, Brasil.

ABSTRACT: Leporinus friderici is a migratory neotropical fish with elevated ecological and economic importance in Brazil. Microsatellite markers are highly important in population genetic studies, management, and conservation programs; however, no markers are available for this species. In this study, seven microsatellite loci, previously developed for Megaleporinus obtusidens, were successfully cross-amplified in L. friderici. Among these loci, five presented moderate to high genetic variability levels, with four to seven alleles per loci and expected heterozygosities varying from $\geq 0.574$ to 1.000 . These markers represent a valuable tool for the future management and ecological studies involving this species and group of neotropical fishes.

Key words: neotropical fish, molecular markers, fish genetics, genetic conservation.

Amplificação cruzada e caracterização de marcadores microssatélites em Leporinus friderici (Characiformes, Anostomidae)

RESUMO: Leporinus friderici é um peixe neotropical migratório com elevada importância ecológica e econômica no Brasil. Os marcadores microssatélites são conhecidos por sua importância em estudos genéticos populacionais, programas de manejo e conservação, no entanto, não existem marcadores disponíveis para esta espécie. Neste estudo, sete locos microssatélites, previamente desenvolvidos para Megaleporinus obtusidens foram amplificados com sucesso em L. friderici. Dentre esses loci, cinco apresentaram variabilidade genética moderada a alta, com quatro a sete alelos por loci e heterozigosidades esperadas variando de $\geq 0,574$ a 1.000. Esses marcadores representam uma ferramenta valiosa para futuros manejos e estudos ecológicos envolvendo esta espécie e este grupo de peixes neotropicais.

Palavras-chave: peixes neotropicais, marcadores moleculares, genética de peixes, genética da conservação.

With a current estimate of 9100 species, South American ichthyofauna is the most diverse on Earth (REIS et al., 2016). The genus Leporinus is among the most diverse fish groups in this region, with approximately 90 described species (BIRINDELLI et al., 2013; BURNS et al., 2014). Leporinus friderici, popularly known as "piau-trêspintas", naturally occurs in Suriname, the Amazon, Paraná and Paraguay River Basins (GODOY, 1987). As a herbivorous fish, this species plays an important ecological role in its ecosystem, and has social and economic importance for local fisheries (OLIVATTI et al., 2011). However, their natural populations are declining in response to several anthropogenic disturbances, such as habitat modifications, water pollution, construction of dams, and the absence of adequate conservation practices (ABELL et al., 2008; BARLETTA et al., 2010).

Microsatellite markers are intensively used in population genetic studies, mainly due to their wide distribution along the eukaryotic genome, high levels of polymorphism, codominance, and high reproducibility (CHISTIAKOV et al., 2006). The development and standardization of molecular markers, such as microsatellites, are cornerstones for the conservation of natural resources (ALLENDORF et al., 2017) and the implementation of adequate and sustainable management in aquaculture. In this study, the cross-species amplification of 15 microsatellite loci, previously developed for Megaleporinus 
obtusidens (VILLANOVA et al., 2015), were tested for $L$. friderici with the aim to provide new markers for future genetic studies. After a systematic and phylogenetic review, L. obtusidens was classified as M. obtusidens by RAMIREZ et al., (2017) due to possible synapomorphies, including a unique ZZ/ZW sex chromosome system, in addition to other characters. This new classification; was subsequently, used in the present study.

Twenty-three $L$. friderici individuals were collected from the Sapucai-Mirim River (Upper Paraná River Basin, São Paulo state, Brazil). Genomic DNA was extracted from fin clips using the "Wizard Genomic DNA Purification Kit" (Promega, Madison, USA). The DNA integrity and its approximate quantification were checked in $1 \%$ agarose gel using the "Low DNA Mass Ladder" of 100 to 2.000 base pairs (bp) (Invitrogen, California, USA). The gel was stained with GelRed (Biotium, Fremont, USA) and observed in a transilluminator under UV light (Loccus Biotecnologia).

The 15 loci developed by VILLANOVA et al. (2015) were amplified by polymerase chain reaction (PCR) in a final volume of $15 \mu \mathrm{L}$, containing $100 \mu \mathrm{M}$ of each dNTP, $1.5 \mathrm{mM} \mathrm{MgCl}_{2}, 1 \times$ Taq buffer, 0.1 units of Taq polymerase (Invitrogen Carlsbad, California, USA), 10 pmol of both forward and reverse PCR primers labeled with fluorescence (NED, PET, $\mathrm{VIC}$, and FAM), and 10-30 ng/ $\mu \mathrm{L}$ of genomic DNA. Thermal cycling was performed on a Verity 96-
Well Thermal Cycler (Applied Biosystems) with an initial denaturation at $95^{\circ} \mathrm{C}$ for $10 \mathrm{~min}, 35$ cycles of denaturation at $94^{\circ} \mathrm{C}$ for $45 \mathrm{~s}$, annealing temperature (between $56{ }^{\circ} \mathrm{C}$ and $60{ }^{\circ} \mathrm{C}$; Table 1) for $50 \mathrm{~s}$, and extension at $72{ }^{\circ} \mathrm{C}$ for $50 \mathrm{~s}$, followed by a final extension step at $72{ }^{\circ} \mathrm{C}$ for $10 \mathrm{~min}$. PCR products were visualized on $2.5 \%$ agarose gel using a 100 bp DNA Ladder (Invitrogen, California, USA), and were stained with GelRed (Biotium Fremont, USA) and observed in a transilluminator under UV light (Loccus Biotecnologia).

Each PCR product was loaded on an automated DNA analyzer (ABI 3730; Applied Biosystems, Foster City, USA) using the 500 LIZ Size Standard (Applied Biosystems, Foster City, USA). Allele sizes were scored using Gene Mapper 3.7 (Applied Biosystems, Foster City, USA). Cervus 3.0 (KALINOWSKI et al., 2007) was used to analyze the polymorphic information content (PIC), total number of alleles per locus $(A)$, allelic range, and expected $\left(H_{\mathrm{E}}\right)$ and observed $\left(H_{\mathrm{O}}\right)$ heterozygosity. Deviations from the Hardy-Weinberg Equilibrium (HWE) and fixing index values $\left(\mathrm{F}_{I S}\right)$ were tested in Genepop 4.0 (ROUSSET, 2008) following the methods of WEIR and COCKERMAN (1984). Microchecker 2.2.3 was used to verify the possibility of genotyping errors or null alleles (VAN OOSTERHOUT et al., 2004).

Among the 15 loci tested, six were successfully amplified in $L$. friderici using different annealing temperatures and proved to be polymorphic

Table 1 - Genetic characterization of seven microsatellite loci for Leporinus friderici.

\begin{tabular}{|c|c|c|c|c|c|c|c|c|c|}
\hline Locus & Motif & $\begin{array}{l}\text { Size range } \\
\quad(\mathrm{bp})\end{array}$ & Primer sequences $\left(5^{\prime}-3^{\prime}\right)$ & $T_{\mathrm{a}}\left({ }^{\circ} \mathrm{C}\right)$ & $P I C$ & $A$ & $H_{\mathrm{O}}$ & $H_{\mathrm{E}}$ & $F_{\text {IS }}$ \\
\hline LoLAR5 & $(\mathrm{ATCC})_{6}$ & $245-480$ & $\begin{array}{c}\text { F:AACCTCCATCTGACACCCATA }{ }^{\text {FAM }} \\
\text { R:GGGACAAAGCGGAGGATAAT }\end{array}$ & 60 & 0.28 & 4 & 0.235 & 0.233 & -0.073 \\
\hline LoLAR6 & $(\mathrm{CTGTT})_{5}$ & $205-230$ & $\begin{array}{c}\text { F:GACGGTGACGAATGTGTGTC } \\
\text { R:TGCAGAAGGCAAAGAACTGA }\end{array}$ & 58 & 0.75 & 6 & 0.650 & 0.808 & $0.176^{* *}$ \\
\hline LoLAR7 & $(\mathrm{CTCCG})_{5}$ & $200-230$ & $\begin{array}{c}\text { F:CAGAGCTGCTCCATGACTGA }{ }^{\text {PET }} \\
\text { R:CTCATGGGAAGCGAGTGTTT }\end{array}$ & 60 & 0.51 & 5 & 0.476 & 0.574 & 0.174 \\
\hline LoLAR17 & $\left(\mathrm{TTAT}_{6}\right.$ & $210-255$ & $\begin{array}{c}\text { F:GCTTGTGTGATTCTCCAGCA } \\
\text { R:TGCACGAGCTACATCAAAGG }\end{array}$ & 58 & 0.08 & 2 & 0.095 & 0.093 & -0.023 \\
\hline LoLAR22 & $(\mathrm{CAA})_{9}$ & $120-150$ & $\begin{array}{c}\text { F:AGCGAGGAGGAAAACAACAA }{ }^{\mathrm{NED}} \\
\text { R:AGCGCCAACTCTTCACTGAG }\end{array}$ & 60 & 0.56 & 4 & 0.650 & 1.000 & $0.562^{* *}$ \\
\hline LoLAR27 & $(\mathrm{TTA})_{9}$ & $110-155$ & $\begin{array}{c}\text { F:ACACCACCATGCTGCCTTAT } \\
\text { R:TTCAM } \\
\text { FATGCATCATTTCAGG }\end{array}$ & 60 & 0.59 & 7 & 0.644 & 0.579 & 0.104 \\
\hline LoLAR37 & $(\mathrm{TG})_{14}$ & $115-135$ & $\begin{array}{c}\text { F:TTAGAGCCCAAGCTCTCGAC } \\
\text { RET } \\
\text { PEGGCCTCGCGTATTTATAG }\end{array}$ & 60 & 0.48 & 6 & 0.532 & 0.632 & -0.193 \\
\hline
\end{tabular}

Base pairs (bp), annealing temperature $\left(T_{\mathrm{a}}\right)$, polymorphic content information $(P I C)$, number of alleles per locus $(A)$, observed $\left(H_{\mathrm{O}}\right)$ and expected $\left(H_{\mathrm{E}}\right)$ heterozygosities, and fixation index $\left(\mathrm{F}_{\mathrm{IS}}\right)$. Asterisks indicate significant deviation from the HWE $\left({ }^{* *} P=0.000\right)$. 
(Table 1), while the other nine loci were monomorphic and excluded from the analysis. The $P I C$ proved to be very informative $(>0.05)$ for loci LoLAR6, LoLAR7, LoLAR22, and LoLAR27, moderately informative (0.25-0.50) for locus LoLAR 37, and not significant $(<0.25)$ for loci LoLAR5 and LoLAR17. The number of alleles per locus $(A)$ ranged from two (LoLARI) to seven (LoLAR27), while the highest $H_{\mathrm{E}}$ values were observed for LoLAR6 and LoLAR22 (0.808 and 1.000, respectively) (Table 1). These same loci presented significant deviations from the HWE $(P<0.000)$ due to homozygote excess $\left(F_{\text {IS }}=0.176\right.$ and 0.562 , respectively) (Table 1$)$. The relatively low number of individuals included in the study might explain these deviations as LoLAR6 and LoLAR22 loci were the most diverse and sampling was probably insufficient to calculate their $H_{\mathrm{E}}$ levels. No evidence for null alleles was suggested by Microchecker, corroborating the results obtained by VILLANOVA et al., (2015).

Cross-species amplification of heterologous microsatellite loci is common when performed for species of the same genus or taxonomically-related genera, as observed in this study and for other Characiformes species (MORELLI et al., 2006). Considering the costs of genomic sequencing and several additional technical steps necessary for the development of new microsatellite markers, data obtained in this study also represent a new possibility of application for other species included in this genus and family.

Overall, the results obtained here make available new useful markers for application in population genetic studies and the conservation of wild populations of $L$. friderici. In the field of genetic management, genetic tools are essential for determining genetic variability, inbreeding, and parentage, and for establishing selective breeding programs in captivity, which are considered essential for sustainable aquaculture (BEAUMONT et al., 2010, ARANEDA et al., 2017).

\section{ACKNOWLEDGEMENTS}

Funding for this study was provided by CTG Brasil (China Three Gorges Corporation), CAPES (Coordenação de Aperfeiçoamento de Pessoal de Nível Superior), CNPQ (Conselho Nacional de Desenvolvimento Científico e Tecnológico) and FAPESP (Fundação de Amparo à Pesquisa do Estado de São Paulo).

\section{DECLARATION OF CONFLICT OF INTERESTS}

The authors declare no conflicts of interest. The founding sponsors played no role in the design of the study, collection, analyses, or interpretation of data, writing of the manuscript, or in the decision to publish the results.

\section{AUTHORS' CONTRIBUTIONS}

The authors contributed equally to this manuscript.

\section{REFERENCES}

ALLENDORF, F. W. Genetics and the conservation of natural populations: allozymes to genomes. Molecular Ecology, v.26, p.420-430, 2017. Available from: <https://onlinelibrary.wiley. com/doi/full/10.1111/mec.13948>. Accessed: Jun. 15, 2019. doi: $10.1111 /$ mec. 13948 .

ABELL, R. et al. Freshwater ecoregions of the world: a new map of biogeographic units for freshwater biodiversity conservation. BioScience, v.58, p.403-414, 2008. Available from: <https:// academic.oup.com/bioscience/article/58/5/403/234819>. Accessed: Mar. 25, 2019. doi: 10.1641/B580507.

ARANEDA, C.,et al., Utility of five SSR markers for genetic diversity and paternity exclusion analysis in the Patagonian toothfish. Latin American Journal of Aquatic Research, v.45, p.188-192, 2017. Available from: <http://lajar.ucv.cl/index.php/ rlajar/article/view/vol45-issue1-fulltext-18/443>. Accessed: Mar. 25, 2019. doi: 10.3856/vol45-issue1-fulltext-18.

BARLETTA, M. et al. Fish and aquatic habitat conservation in South America: a continental overview with emphasis on neotropical systems. Journal of Fish Biology, v.76, p.2118-2176, 2010. Available from: $<$ https://onlinelibrary.wiley.com/doi/abs/10 $.1111 /$ j.1095-8649.2010.02684.x>. Accessed: Jan. 20, 2019. doi: 10.1111/j.1095-8649.2010.02684.x.

BEAUMONT, A., BOUDRY, P., HOARE, K. Biotechnology and genetics in fisheries and aquaculture. John Wiley \& Sons, 2010. Available from <https://onlinelibrary.wiley.com/doi/ book/10.1002/9781444318791>. Accessed: May, 18, 2020. doi: $10.1002 / 9781444318791$.

BIRINDELLI, J. L. O. et al. Two new species of Leporinus (Characiformes: Anostomidae) from the Brazilian Amazon, and redescription of Leporinus striatus Kner 1858. Journal of Fish Biology, v.83, p.1128-1160, 2013. Available from: <https://doi. org/10.1111/jfb.12206>. Accessed: Feb. 20, 2019. doi: 10.1111/ jfb. 12206.

BURNS, M. D. et al. A new species of Leporinus (Characiformes: Anostomidae), from the Orinoco Basin, Venezuela. Copeia, v.2, p.206-214, 2014. Available from: <https://doi.org/10.1643/CI-13071>. Accessed: Jan. 20, 2019. doi: 10.1643/CI-13-071.

CHISTIAKOV, D. A. et al. Microsatellites and their genomic distribution, evolution, function and applications: a review with special reference to fish genetics. Aquaculture, v.255, p.1-29, 2006. Available from: <https://doi.org/10.1016/j.aquaculture.2005.11.031>. Accessed: Apr. 10, 2019. doi: 10.1016/j.aquaculture.2005.11.031.

GODOY, M. P. Peixes do Estado de Santa Catarina. Editora da Universidade Federal de Santa Catarina, Florianopolis, 1987. 57p.

KALINOWSKI, S. T. et al. Revising how the computer program CERVUS accommodates genotyping error increases success in paternity assignment. Molecular Ecology, v.16, p.1099-1106, 2007. Available from: <https://onlinelibrary.wiley.com/doi/ abs/10.1111/j.1365-294X.2007.03089.x>. Accessed: Jul. 10, 2019. doi: 10.1111/j.1365-294X.2007.03089.x. 
MORELLI, K. A. et al. Isolation and characterization of eight microsatellite loci in Leporinus macrocephalus (Characiformes: Anostomidae) and cross-species amplification. Molecular Ecology Notes, v.7, p.32-34, 2006. Available from: $<$ https://onlinelibrary.wiley. com/doi/abs/10.1111/j.1471-8286.2006.01484.x>. Accessed: Apr. 06, 2020. doi: $10.1111 / \mathrm{j} .1471-8286.2006 .01484 . x$.

OLIVATTI, A. M. et al. Heterologous amplification and characterization of microsatellite markers in the Neotropical fish Leporinus friderici. Genetics and Molecular Research, v.10, p.1403-1408, 2011. Available from: <https://www.geneticsmr. org/articles/heterologous-amplification-and-characterization-ofmicrosatellite-markers-in-the-neotropical-fish-leporinus-friderici. pdf $>$. Accessed: Feb. 15, 2019. doi: 10.4238/vol10-3gmr1020.

REIS, R. E. et al. Fish biodiversity and conservation in South America. Journal of Fish Biology, v.89, p.12-47, 2016. Available from: <https://doi.org/10.1111/jfb.13016>. Accessed: Nov. 15, 2019. doi: $10.1111 / \mathrm{jfb} .13016$.

RAMIREZ, J. L. et al. A new genus of Anostomidae (Ostariophysi: Characiformes): diversity, phylogeny and biogeography based on cytogenetic, molecular and morphological data. Molecular Phylogenetics and Evolution, v.107, p.308-323, 2017. Available from: <https://doi.org/10.1016/j.ympev.2016.11.012>. Accessed: Feb. 15, 2019. doi: 10.1016/j.ympev.2016.11.012.
ROUSSET, F. Genepop'007: a complete re-implementation of the genepop software for Windows and Linux. Molecular Ecology Resources, v.8, p.103-106, 2008. Available from: <https://doi.org/ 10.1111/j.1471-8286.2007.01931.x>. Accessed: Jan. 10, 2019. doi: 10.1111/j.1471-8286.2007.01931.x.

VAN OOSTERHOUT, $C$. et al. MICRO-CHECKER: software for identifying and correcting genotyping errors in microsatellite data. Molecular Ecology Notes, v.4, p.535-538, 2004. Available from: <https://doi.org/10.1111 /j.1471-8286.2004.00684.x>. Accessed: Apr. 15, 2019. doi: 10.1111/j.1471-8286.2004.00684.x

VILLANOVA, G. V. et al. Isolation and characterization of 20 polymorphic microsatellite loci in the migratory freshwater fish Leporinus obtusidens (Characiformes: Anostomidae) using 454 shotgun pyrosequencing. Journal of Fish Biology, v.86, p.1209-1217, 2015. Available from: $<$ https://doi.org/10.1111/jfb.12632>. Accessed: Apr. 15, 2019. doi: $10.1111 / \mathrm{jfb} .12632$.

WEIR, B. S. et al. Estimating F-statistics for the analysis of population structure. Evolution, Lancaster, v.38, p.1358-1370, 1984. Available from: <https://onlinelibrary.wiley.com/doi/ abs/10.1111/j.15585646.1984.tb05657.x>. Accessed: Apr. 06, 2020. doi: 10.1111/j.15585646.1984.tb05657. 